\begin{tabular}{|l|l|l||}
\hline \multicolumn{2}{|c|}{ PublisherInfo } \\
\hline \hline PublisherName & $:$ & BioMed Central \\
\hline \hline PublisherLocation & $:$ & London \\
\hline \hline PublisherImprintName & $:$ & BioMed Central \\
\hline \hline
\end{tabular}

\title{
Many mutant mice
}

\begin{tabular}{|l|l|l||}
\hline \multicolumn{2}{|c|}{ ArticleInfo } \\
\hline \hline ArticleID & $:$ & 3741 \\
\hline \hline ArticleDOI & $:$ & $10.1186 /$ gb-spotlight-20000810-02 \\
\hline \hline ArticleCitationID & $:$ & spotlight-20000810-02 \\
\hline \hline ArticleSequenceNumber & $:$ & 178 \\
\hline \hline ArticleCategory & $:$ & Research news \\
\hline ArticleFirstPage & $:$ & 1 \\
\hline \hline ArticleLastPage & $:$ & 2 \\
\hline \hline & $:$ & RegistrationDate : 2000-08-10 \\
ArticleHistory & $:$ & OnlineDate \\
\hline \hline ArticleCopyright & $:$ & BioMed Central Ltd2000-08-10 \\
\hline \hline ArticleGrants & $:$ & \\
\hline \hline ArticleContext & $:$ & 130591111 \\
\hline \hline
\end{tabular}


William Wells

Email:wells@biotext.com

In the August Nature Genetics, two groups report on their ongoing large-scale projects to produce mouse mutants using the chemical mutagen ethylnitrosourea. An English and French group have screened over 26,000 F1 progeny for dominant defects in growth and development, and a subset of these for defects in neural and behavioral function and blood chemistry (Nolan et al., Nat. Genet. 2000, 25:440-443). Their results are cataloged in Mutabase. Approximately half of the phenotypes are heritable, and an extrapolation from present numbers suggests a final count of about 500 mutants. These mutants (with phenotypes in parentheses) include such memorable additions as spin cycle (head bobbing, fits), nanomouse (small and pointed head), and van gogh (craniofacial, lowered ear).

The second effort, by Hrabe de Angelis et al., is part of the German Human Genome Project (Nat. Genet. 2000, 25:444-447). As detailed on the group's home page, over 14,000 F1 mice have been screened for dominant defects, and a smaller screen is underway to uncover recessive mutations. Both groups are proceeding with mapping studies, and offer free access to mutant lines for non-commercial users.

\section{References}

1. Nature Genetics, [http://www.nature.com/ng/]

2. Mutabase, [http://www.mgu.har.mrc.ac.uk/mutabase]

3. The ENU-mouse mutagenesis screen project, [http://www.gsf.de/ieg/groups/enu-mouse.html] 